\title{
Module engine operating on example of Pratt\&Whitney F100-PW-229
}

\begin{abstract}
The article presents operation of Pratt\&Whitney jet engine F100-PW-229 used in F-16 planes used by Polish Air Forces. The description bases on general construction of the engine and focuses on its modularity. Besides, there has been described the rules of operation of F100-PW-229 engines. The article concentrates also on specifics of maintenance and repairs of module engines and competence of flight squadrons for performing such repairs.
\end{abstract}

Key words: combustion engine, jet engine

\section{Eksploatacja silników o modułowej budowie na przykładzie F100-PW-229 firmy Pratt\&Whitney}

\begin{abstract}
W artykule przedstawiono charakterystyke odrzutowego silnika F100-PW-229, firmy Pratt\&Whitney, stosowanego w samolotach F-16, będacych w posiadaniu Polskich Sit Powietrznych. Opisano ogólna budowę tego silnika, zwracając szczególnq uwage na jej modułowość. Przedstawiono zasady eksploatacji silników F100-PW-229 obowiąujące w jednostkach Polskich Sit Powietrznych. Opisano specyfikę prac obstugowo-naprawczych silników o budowie modutowej oraz kompetencje jednostek organizacyjnych eskadr lotniczych do prowadzenia prac w tym zakresie.
\end{abstract}

Słowa kluczowe: silnik spalinowy, silnik odrzutowy

\section{Introduction}

When Polish Air Forces have purchased F-16s, 31st Tactical Air Base in Krzesiny and 32nd Tactical Air Base in Łask have started to use Pratt\&Whitney F100-PW-229 module engines. It has enabled repairs which have earlier been done by repair workshops to be performed directly by the user. Due to huge range of repairs, their complexity and need of advanced training of technical personnel, units using F-16 planes and their engines have been prepared for new way of work organization. Use of modern engines introduced new quality, new challenges and greater independence into maintenance and repairs.

\section{General characteristic of F100-PW-229 engine}

F100-PW-229 engine (Fig. 1) is a module, biflow jet engine with afterburner. The engine creates maximum thrust of $79.1 \mathrm{kN}$ and $129.6 \mathrm{kN}$ with afterburner. Engine thrust to its mass ratio is $8: 1$. F100-PW-229 is an engine biflow factor is $0.36: 1$ and high level of compressing (32:1). Low pressure compressor has 3 levels and high pressure compressor -10 levels. Both compressors are equipped with air flow control systems. The engine has a ring combustion chamber. Low and high pressure turbine has 2 levels. Exhaust nozzle is divergent - convergent and its section is adjustable. Engine overhead shafting bases on bearings. Digital Electronic Engine Control (DEEC) electronic system is responsible for controlling engine work parameters. Fuel is directed to the engine through fuel pomp. (Main Fuel Control - MFC) and afterburner pump (Augmentor Fuel Control AFC).

F100-PW-229 engine bases on a module concept of structure which enables to disassemble functionally and physically connected parts. Modules are treated as individual subgroups of engine. In case of a serious faultiness the module concept makes the process of restoring the engine to operation faster. It is possible to replace the damaged

\section{Wstęp}

Wraz z zakupem samolotów F-16 dla Polskich Sił Powietrznych rozpoczęła się w 31. Bazie Lotnictwa Taktycznego w Krzesinach i 32. Bazie Lotnictwa Taktycznego w Łasku eksploatacja silników F100-PW-229 firmy Pratt\&Whitney. Modułowa budowa silników umożliwiła wykonywanie części napraw, realizowanych dotychczas przez zakłady remontowe, bezpośrednio przez użytkownika. W związku ze znacznym rozszerzeniem zakresu wykonywanych prac, ich złożonością, jak również koniecznością prowadzenia zaawansowanego szkolenia personelu technicznego, jednostki eksploatujące samoloty F-16 i ich silniki przystosowano do nowej organizacji pracy. Rozpoczęcie eksploatacji nowoczesnych silników wniosło do pracy personelu technicznego nową jakość, nowe wyzwania oraz znacznie większą samodzielność w prowadzeniu obsługi i napraw.

\section{Ogólna charakterystyka budowy silnika F100-PW-229}

Silnik F100-PW-229 (rys. 1) jest silnikiem odrzutowym $\mathrm{z}$ dopalaczem, dwuprzepływowym o modułowej budowie. Silnik wytwarza ciąg maksymalny $79,1 \mathrm{kN}$, a z dopalaczem 129,6 kN. Stosunek ciągu silnika do jego masy wynosi 8:1. F100-PW-229 jest silnikiem o niskim współczynniku dwuprzepływowości, wynoszącym 0,36:1 i wysokim stopniu sprężania 32:1. Sprężarka niskiego ciśnienia ma 3 stopnie, a wysokiego ciśnienia - 10. Obie sprężarki wyposażone są w układy sterujące przepływem powietrza. W silniku zastosowana jest pierścieniowa komora spalania. Turbina wysokiego oraz niskiego ciśnienia jest dwustopniowa. Dysza wylotowa jest zbieżno-rozbieżna o regulowanym przekroju. Pędnia silnika została oparta na 5. łożyskach. Za sterowanie i kontrolę parametrów pracy silnika odpowiada układ elektroniczny DEEC (Digital Electronic Engine Control). 


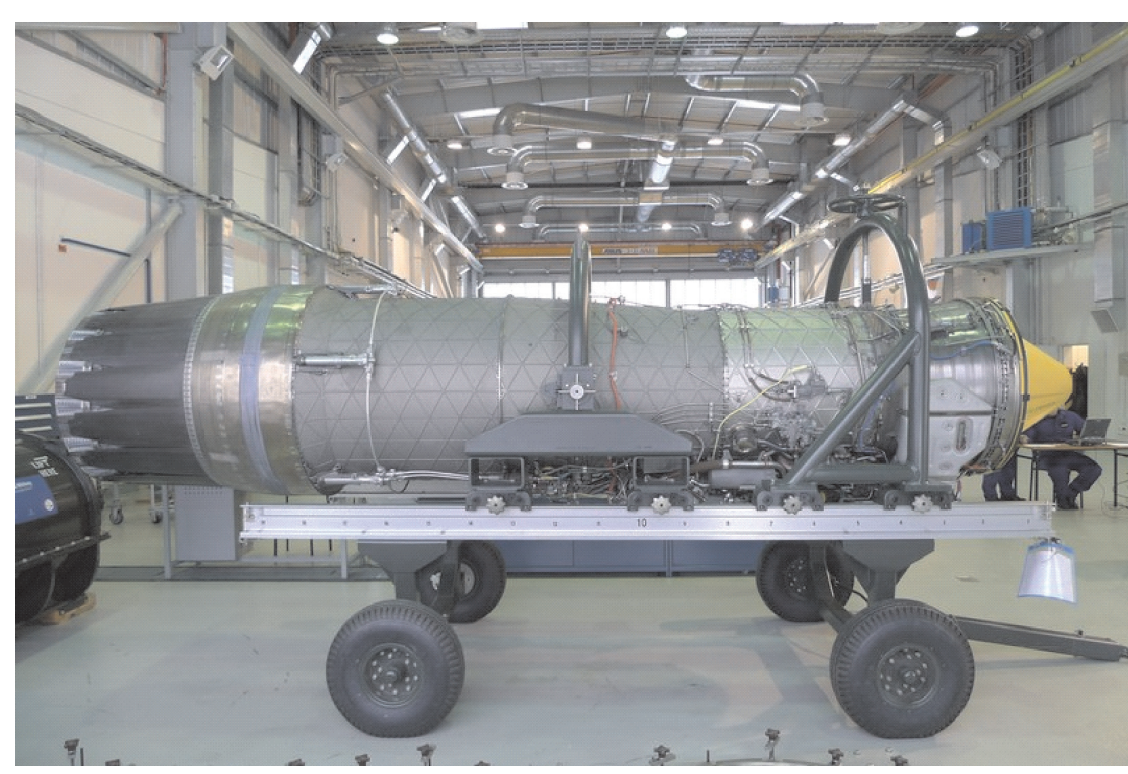

Fig. 1. Pratt\&Whitney F100-PW-229 engine

Rys. 1. Silnik F100-PW-229 firmy Pratt\&Whitney

module with a new one without having to install a repaired module removed from the engine. Module configuration allows also to replace subgroups and parts of the engine as such method is claimed to be most effective in improving engine functioning. F100-PW-229 engine comprises the following modules:

a) Fan module (Fig. 2)

In this module 3-level low pressure compressor delivers compressed air to an area where air is divided into outer and inner flow.

b) Main module of the engine (Fig. 3)

This module comprises the area of air flow section, 10-level compressor of high pressure, ring combustion chamber and 2-level turbine of high pressure. Besides, the main module provides drive for a box of generators' drive.

c) Module of fan turbine drive (Fig. 4)

Low pressure turbine comprises 2 levels and is combined with the low pressure compressor by shaft and provides its drive.

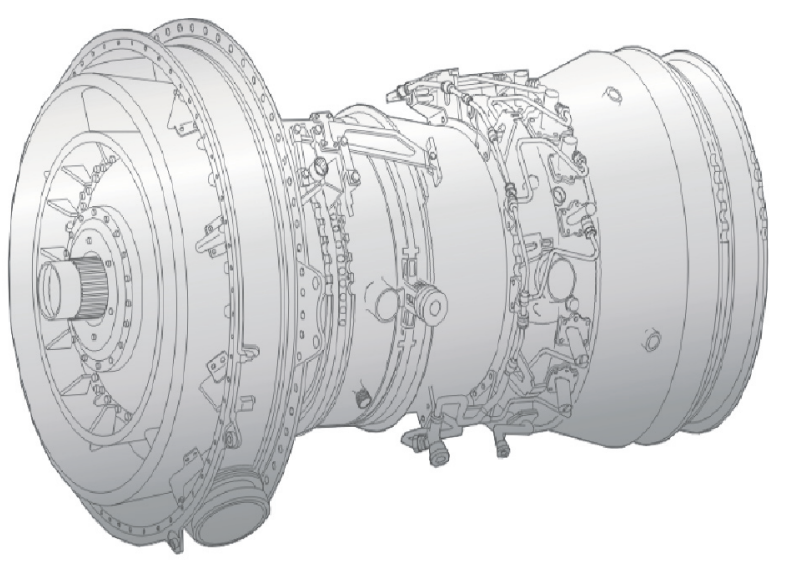

Fig. 3. Main module of the engine Rys. 3. Modut główny silnika
Paliwo doprowadzane jest do silnika przez pompę paliwa MFC (Main Fuel Control) oraz pompę paliwa dopalacza AFC (Augumentor Fuel Control).

Silnik F100-PW-229 bazuje na modułowej koncepcji budowy, pozwalającej wykonywać demontaż funkcjonalnie i fizycznie połączonych części. Moduły są traktowane jako indywidualne podzespoły silnika. W sytuacji poważnej niesprawności koncepcja ta usprawnia i przyspiesza proces przywracania silnika do eksploatacji. Istnieje możliwość szybkiego zainstalowania innego sprawnego modułu, bez konieczności oczekiwania na naprawę modułu niesprawnego, wybudowanego z silnika. Modułowa konfiguracja pozwala także na wymianę podzespołów i części silnika, gdyż naprawa taka jest uważana za najefektywniejszą metodę usprawnienia silnika.

W skład silnika F100-PW-229 wchodzą następujące moduły:

a) Moduł wentylatora (rys. 2)

W module tym trzystopniowa sprężarka niskiego ciśnienia dostarcza sprężone powietrze (spręż około 4) do strefy podziału przepływu, gdzie następuje podział powietrza na przepływ zewnętrzny i wewnętrzny.

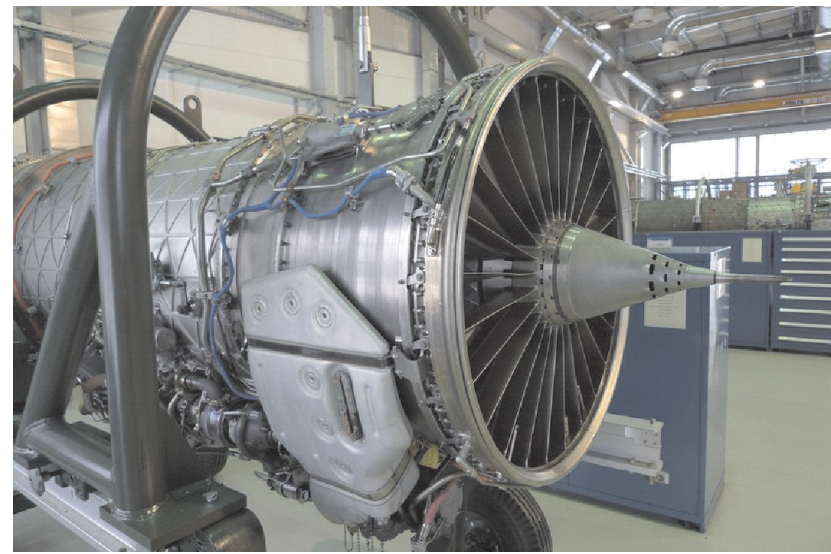

Fig. 2. Fan module

Rys. 2. Modut wentylatora

b) Moduł główny silnika (rys. 3)

Moduł ten składa się ze strefy podziału przepływu, 10-stopniowej sprężarki wysokiego ciśnienia, pierścieniowej komory spalania i 2-stopniowej turbiny wysokiego ciśnienia. Ponadto moduł główny zapewnia napęd dla skrzynki napędu agregatów.

c) Moduł turbiny napędu wentylatora (rys. 4)

Turbina niskiego ciśnienia składa się z 2 stopni, połączona jest za pomocą wału ze sprężarką niskiego ciśnienia i zapewnia jej napęd. 


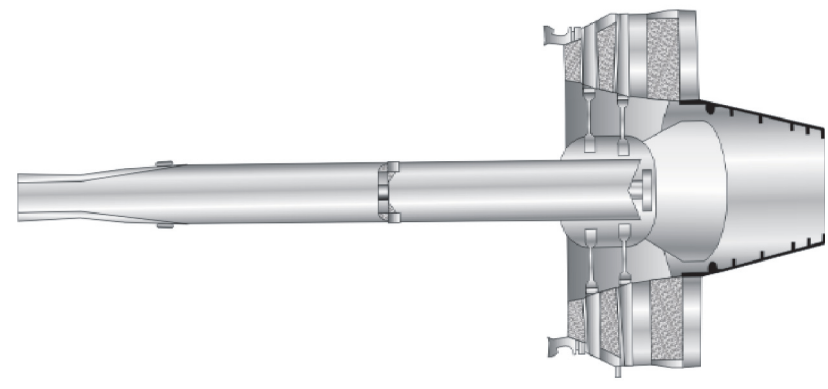

Fig. 4. Module of fan turbine drive Rys. 4. Modut turbiny napędu wentylatora

d) Afterburner module (Fig. 5)

This module comprises: chamber of afterburner and nozzle. The nozzle is divergent - convergent and its section is adjustable.

e) Module of generators' drive box (Fig. 6)

This module is installed in the lower part of the engine. Drive is moved by a vertical shaft from the main module. Module of generator drive comprises: reductive box of generator drive, oil pump, oil filter and four magnetic detectors.

F100-PW-229 engine comprises also other parts and generators which are not included in module. These are: front and back outer channel of the engine (Fig. 7) which form outer casing of the engine and channel for outer circulation of the air.

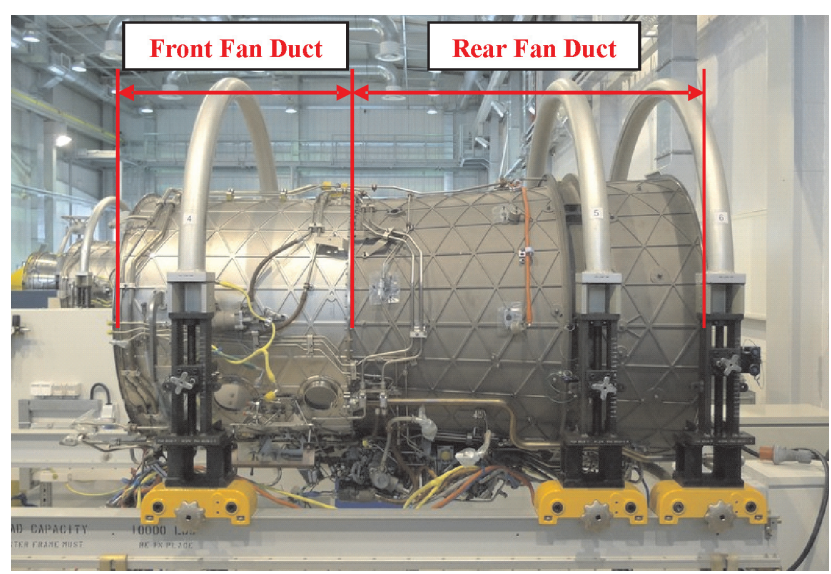

Fig. 7. Front and back outer channel of the engine Rys. 7. Przedni i tylny kanat zewnętrzny silnika

\section{Use of F100-PW-229 engine and levels of operation}

When operating of F-16 planes has started, the structure of the flight units had to be adapted in order to perform maintenance work.

Many standard specializations have been divided into more specialized as far as maintenance works are concerned.

In the maintenance squadrons there have been formed Engine Exploitation Keys. In the Technical Squadron appeared d) Moduł dopalacza (rys. 5)

Moduł ten składa się z komory spalania dopalacza i dyszy. Dysza jest zbieżno-rozbieżna o regulowanej powierzchni przekroju.

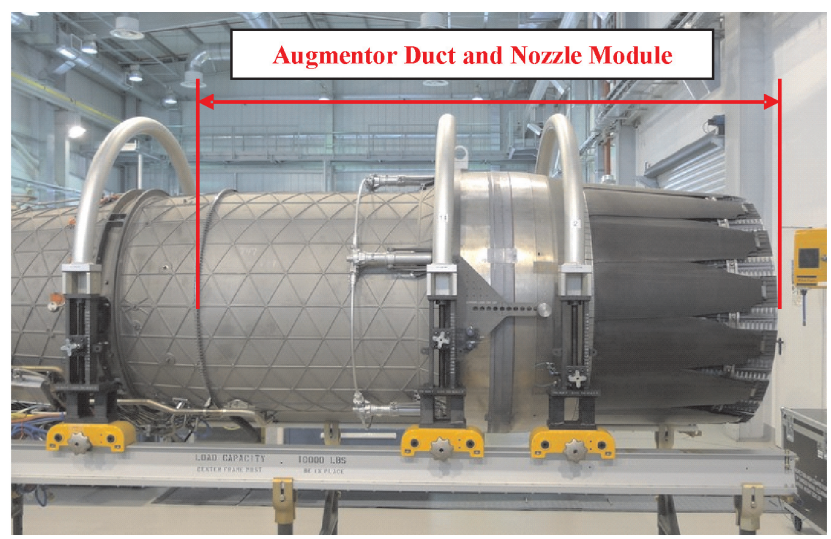

Fig. 5. Afterburner module

Rys. 5. Modut dopalacza

e) Moduł skrzynki napędu agregatów (rys. 6)

Moduł ten zainstalowany jest w dolnej części silnika. Napęd przenoszony jest za pomocą pionowego wałka z modułu głównego. Moduł napędu agregatów składa się ze skrzynki redukcyjnej napędu agregatów, pompy olejowej, filtra olejowego i 4 detektorów magnetycznych.

W budowie silnika F100-PW-229 można wyróżnić także elementy pozamodułowe. Są to dodatkowe części i agregaty, które nie wchodzą w skład modułów. Do elementów pozamodułowych zalicza się przedni i tylni kanał zewnętrzny silnika (rys. 7), które stanowią zewnętrzną obudowę silnika,

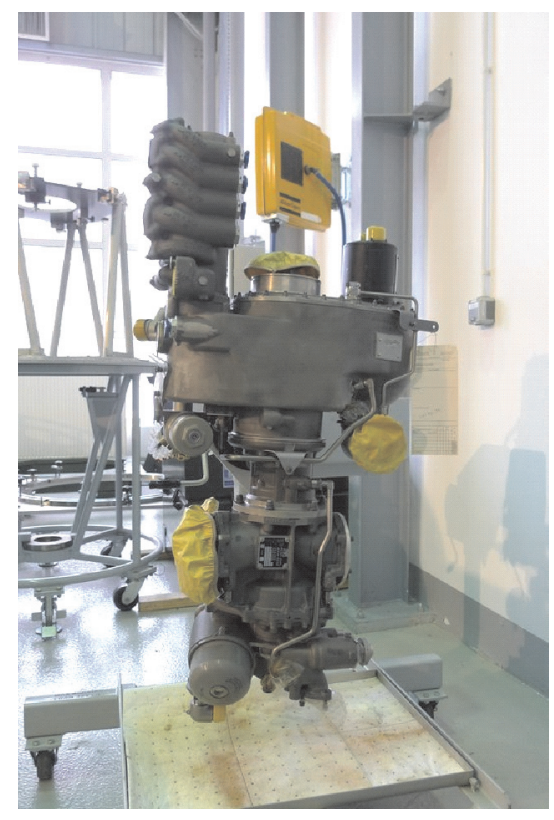
(in vertical position)

Rys. 6. Modut skrzynki napędu agregatów (w pozycji pionowej)
Fig. 6. Module of generator drive box jak również tworzą kanał zewnętrznego obiegu strumienia powietrza.

\section{Eksploatacja silników F100-PW-229, poziomy eksploatacji}

Wraz z rozpoczęciem eksploatacji samolotów F-16 należało dostosować strukturę jednostek lotniczych do realizacji 
Engine Maintenance and Repair Key which comprises:

- Engine Maintenance \& Repair Workshop

- Engine Operation Workshop

- Engine Diagnostic Laboratory

F-100-PW 229 engines are used at 3 levels:

- Basic level - Organizational Level (O-Level) - is performed by engine maintenance and repair keys. It involves engine inspections and LRU type (Line Replacement Units) Repairs are performed at engines installed in airframes.

- Intermediate Level (I-level) - performed by the engine maintenance and repair key in technical squadrons. This level involves major repairs of engines. I-Level is performed only by the 31st Tactical Air Base in Krzesiny.

- Depot Level (D-level) - involves modules repairs when range of damages exceeds repair capabilities of the air base.

Engine operation is performed by maintenance squadrons. Engines are checked by technicians before and after flight in question of compressors damages caused by foreign objects, filings in engine oil and all kind of leaks. During flight, electronic systems of an engine are constantly monitoring operation parameters. All faults in engine functioning important for pilots are displayed in cabin MFL faults (Maintenance Fault List). After a flight, a pilot communicates with the technical personnel in question of plane and engine functioning. During maintenance after flight, parameters of the engine are checked by a special device called CETS (Common Engine Transfer Set). These data include also additional information concerning faults which have not been reported to a pilot and all data concerning overhaul life. Analysis of the data is performed in computer system of engine operation support called EMMS (Engine Monitoring \& Management System) which is currently being replaced by a new system EMATS (Engine Management \& Tracking System). Collected data help to manage engine operation and afterwards they are archived.

EMATS system is used for register all maintenance and repair works and engine use data. The system enables:

- register of maintenance work performed on particular module/engine

- generating of work plans which include activities to be performed during particular maintenance/of an engine or a module

- monitoring of the history of events which have occurred in an engine/module or its generators

- tracking earlier places where engines, modules and generators have earlier been installed

- forecasting of the dates of maintenance works

- preparing registers and operating bulletins (TCTOs)

- creating of overhaul life reports

- connecting with CETS system in order to transfer data directly from engines.

EMATS software is used by all the keys dealing with engines' operation. When there is a fault which can not be repaired by Engine Operation Key of Maintenance Squadron, the engine is removed from airframe and handed over to the obsług samolotów na zasadach określonych przez producenta. Dokonano rozdzielenia wielu ,klasycznych” specjalności na mniejsze, bardziej wyspecjalizowane w prowadzonych przez nie czynnościach obsługowych. W Eskadrach Obsługi utworzono Klucze Eksploatacji Silnika (KES). W Eskadrze Technicznej powstał Klucz Obsługi i Naprawy Silnika (KOiNS), w skład którego wchodzą:

- Warsztat Obsługi i Naprawy Silnika

- Warsztat Zabezpieczenia Eksploatacji Silnika

- Laboratorium Diagnozowania Silnika.

Eksploatację silników F100-PW-229 prowadzi się na 3 poziomach:

- Poziom podstawowy - Organizational Level (O-Level) - wykonywany jest przez klucze eksploatacji silnika w eskadrach obsługi. Na poziomie tym przeprowadza się serwisowanie silnika, przeglądy i wymiany agregatów typu LRU (Line Replacement Units). Czynności naprawcze są prowadzone na silnikach zabudowanych w płatowcach.

- Poziom średni - Intermediate Level (I - Level) - prowadzony jest przez klucz obsługi i naprawy silnika eskadry technicznej. Zakres obsługi silników i naprawy modułów obejmuje poważne naprawy i weryfikację silników kierowanych do remontu. Przed skierowaniem do klucza obsługi i naprawy silnika, silniki są demontowane z samolotów. Poziom obsług I - Level prowadzony jest tylko przez Bazę Lotnictwa Taktycznego w Krzesinach dla obu jednostek dysponujących samolotami F-16.

- Poziom remontowy - Depot Level (D - Level) - na tym poziomie odbywa się remont modułów oraz ich naprawa wtedy, gdy zakres uszkodzeń przekracza możliwości naprawcze bazy lotniczej.

Eksploatacja silników zabudowanych na samolotach prowadzona jest przez eskadry obsługi. Silniki są sprawdzane przez techników samolotów przed i po wylocie pod względem występowania uszkodzeń sprężarek przez ciała obce, obecności opiłków w oleju silnikowym i wszelkiego rodzaju wycieków. Podczas lotu układy elektroniczne silnika w sposób ciągły prowadzą monitorowanie parametrów eksploatacyjnych. Wszelkiego rodzaju istotne dla pilota nieprawidłowości w działaniu silnika są komunikowane na wyświetlaczach w kabinie w postaci błędów MFL (Maintenance Fault List). Uwagi na temat pracy samolotu i silnika są przekazywane po przylocie przez pilota personelowi technicznemu. Podczas obsługi polotowej specjalista z Klucza Eksploatacji Silnika odczytuje parametry pracy silnika za pomocą urządzenia CETS (Common Engine Transfer Set). Dane te zawierają dodatkowe informacje o innych błędach, które nie były raportowane pilotowi, oraz wszystkie dane resursowe. Analiza danych odbywa się w informatycznym systemie wsparcia eksploatacji silników EMMS (Engine Monitoring \& Management System), zastępowanym obecnie nowym systemem EMATS (Engine Management and Tracking System). Zebrane dane pomagają odpowiednio zarządzać eksploatacją silnika, a następnie są archiwizowane.

System EMATS jest używany do ewidencji wszystkich obsług, prac remontowych i danych eksploatacyjnych silników. System umożliwia: 
Engine Operation and Repair Key. Engine acceptance starts with an acceptance inspection during which the following activities are done:

- visual inspection

- performing checks described in documents

- inspection of engine's gase duct.

Before commencing engine repair, key commander organizes planistic briefing during which all questions concerning engine repair are discussed, including:

- analysis of deficiencies and defects

- choosing parts necessary for performing repair and ordering them in case when they are not in store

- planning which bulletins can be done only during engine disassembly

- fixing plan of work

- choosing proper documents which constitute a base for repair work

- preparing documents concerning engine repair.

Time of engine repair is connected with the way it is done. When it is necessary to repair a module and there is no spare module, repair lasts much longer. Moreover, during engine disassembly it is possible to identify other serious fault which needs additional repair works. All repairs performed by Engine Maintenance \& Repair Key are identified in IETM documents which are stored in mobile computers and necessarily used by technical personnel during all works done by the use of equipment. When a repair is done, engine check is performed before it comes back to hush house. 31st Tactical Air Base in Krzesiny has hush house at its disposal (Fig. 8 and 9) where there are performed engine tests in full operating range. Hush house has been adopted to perform tests of engines installed in airframes and removed from them. Engine Diagnosis Laboratory is equipped with a very modern control system for control and measuring purposes. The hush house meets severe requirements concerning noise level. It has been equipped with special silencers providing noise limitations during engines' testing. After tests are finished, engine is taken back to a workshop where final inspection is performed. Next, engine is handed over to a user in order to be installed in an aircraft.

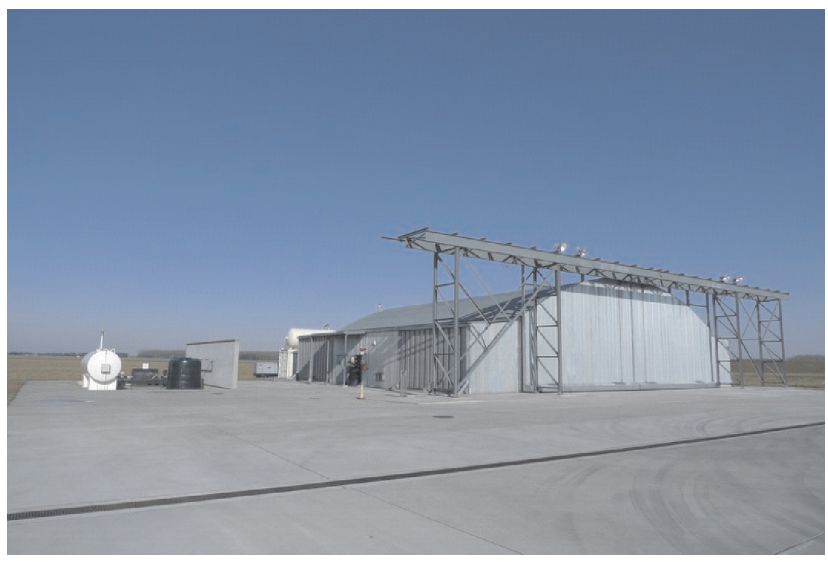

Fig. 8. Hush house in the 31st Tactical Air Base in Krzesiny

Rys. 8. Hamownia 31. Bazy Lotnictwa Taktycznego w Krzesinach
- ewidencję wykonywanych czynności obsługowych na danym module/silniku

- generowanie planów pracy, które zawierają czynności do wykonania podczas danej obsługi/przeglądu silnika lub modułu

- podgląd historii zdarzeń, które wystąpiły na danym silniku/ module lub jego agregatach

- śledzenie wcześniejszych miejsc zabudowy silników, modułów i agregatów

- prognozowanie terminów wykonywania obsług, wymian agregatów, kierowania modułów do remontu

- ewidencję i wykonanie biuletynów eksploatacyjnych TCTO

- generowanie raportów resursowych

- podłączenie do systemu CETS w celu przesyłania danych bezpośrednio z silników.

Obsługa oprogramowania EMATS jest prowadzona na poziomie wszystkich kluczy eksploatujących silniki. Po stwierdzeniu niesprawności, której naprawa przekracza możliwości Klucza Eksploatacji Silników Eskadry Obsługi, silnik wybudowywany jest z płatowca i przekazywany do Klucza Eksploatacji i Naprawy Silników. Przyjęcie silnika rozpoczyna przegląd odbiorczy, w trakcie którego odbywa się:

- przegląd wizualny,

- wykonanie sprawdzeń nakazanych dokumentacją,

- przegląd boroskopowy traktu gazowego silnika.

Przed przystąpieniem do naprawy silnika dowódca klucza przeprowadza odprawę planistyczną, podczas której są omawiane wszystkie zagadnienia związane z naprawą silnika, w tym:

- analizuje się niesprawność i wykryte defekty

- ustala się potrzebne do naprawy części, które następnie są rezerwowane przez kierownika Warsztatu Zabezpieczenia Eksploatacji, lub w przypadku ich braku zamawiane

- planuje się realizację biuletynów możliwych do wykonania tylko podczas rozbiórki silnika

- ustala się plan pracy

- wybiera odpowiednie dokumenty stanowiące podstawę prac naprawczych

- zakłada się dokumentację naprawy silnika.

Czas naprawy silnika wynika ze sposobu jej wykonania. Gdy zaistnieje konieczność naprawy modułu, a brak jest modułu zapasowego, czas znacząco się wydłuża. Dodatkowo w trakcie rozbiórki silnika istnieje możliwość zidentyfikowania innej poważnej niesprawności, która wymaga dodatkowych czynności naprawczych. Wszystkie obsługi prowadzone przez Klucz Obsługi i Naprawy Silnika są określone w dokumentacji IETM (Interactive Electronic Technical Manual). Dokumentacja przechowywana jest w komputerach przenośnych i obowiązkowo wykorzystywana przez personel techniczny podczas wszystkich czynności wykonywanych na sprzęcie.

Po wykonaniu naprawy odbywa się przegląd silnika przed skierowaniem go na hamownię. 31. Baza Lotnictwa Taktycznego w Krzesinach dysponuje hamownią (rys. 8 i 9), na której prowadzone są próby silników w pełnym zakresie 


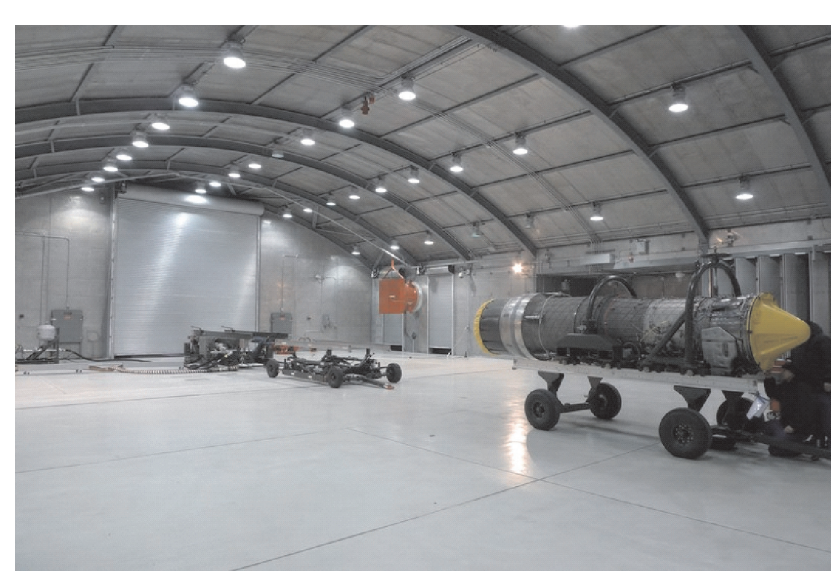

Fig. 9. Engine tests stand in the 31st Tactical Air Base in Krzesiny Rys. 9. Stanowisko prób silników w 31. Bazie Lotnictwa Taktycznego w Krzesinach

\section{Engine modules operation}

F100-PW229 engine operation based on cycles. Such operation deals with constant defining of changes of engine work and, on this basis, overhaul life is count.

Data is collected in system of operation support (EMATS). Modules have overhaul life of 4300 cycles. Some group of generators is operated on the basis of separate overhaul life.

Module replacement is performed in the following cases:

- end of overhaul life between repairs

- loss of operating characteristic

- great likelihood of damage.

Proper inspection over engine module operation and maintenance procedures obeying enables more effective use of overhaul life, longer time engine use in an aircraft and cost lowering. Module engine operation is very comfortable however it requires a lot from user. Every engine can be quickly returned to operation as there is no need to wait for a module repair. It is the greatest advantage of this type of engines. Disassembled, damaged modules can be repaired independently from the whole engine. In the meantime, a spare module is installed in and the engine is handed over to use. After repair, the damaged module becomes a spare part. However, the number of spare modules and engines is limited and due to this fact, replacement changes are also limited.

Engine Maintenance \& Repair Key of 31 Airbase in Krzesiny can perform most of maintenance and repair works, like:

- "longlasting" module repairs, including very difficult repair of main module

- checking generators, engine and modules' parts

- mechanical processing of the parts, repair or reconstruction of riveted joints and welding of hard metals (cobalt alloys)

- reconstruction of the parameters of engine functioning and their verification in engine hush house

- tests at hush house for damaged engines before commencing their repair - it is necessary in case of damages eksploatacyjnym. Hamownia została przystosowana do przeprowadzania prób silników wybudowanych i zabudowanych w płatowcach. Laboratorium Diagnozowania Silnika wyposażone jest w bardzo nowoczesny system sterowania i sprzęt kontrolno-pomiarowy. Hamownia spełnia surowe normy dotyczące hałasu. Wyposażono ją w specjalne thumiki zapewniające ograniczenia hałasu podczas testowania silników lotniczych. Po przeprowadzeniu prób silnik wraca do warsztatu, gdzie przeprowadzany jest na nim końcowy przegląd kontrolny. Następnie silnik zostaje przekazany użytkownikowi w celu zabudowy w samolocie.

\section{Eksploatacja modułów silnikowych}

Silnik F100-PW229 jest eksploatowany według cykli. Eksploatacja taka polega na ciągłym określaniu zmian parametrów pracy silnika i na tej podstawie wyliczaniu zużycia resursu. Zużycie resursu jest określone oddzielnie dla poszczególnych modułów, a nie dla całego silnika. Dane są gromadzone w systemie wsparcia eksploatacji EMATS. Moduły ( $\mathrm{z}$ wyjątkiem modułu napędu agregatów) mają nadany resurs do remontu, wynoszący 4300 cykli. Pewna grupa agregatów jest eksploatowana według oddzielnego resursu. Wymianę modułów przeprowadza się w następujących przypadkach:

- koniec resursu międzyremontowego

- utrata charakterystyk eksploatacyjnych

- duże prawdopodobieństwo uszkodzenia.

Właściwe prowadzenie nadzoru nad eksploatacją silników i modułów oraz przestrzeganie procedur obsługowych umożliwia efektywniejsze wykorzystanie resursów, dłuższy czas eksploatacji silnika w samolocie i zmniejszenie kosztów. Eksploatacja silników o budowie modułowej jest bardzo wygodna, jednakże stawia przed użytkownikiem również spore wymagania. Każdy silnik można szybko przywrócić do eksploatacji, gdyż nie zachodzi potrzeba oczekiwania na naprawę modułu. Jest to największa zaleta silników o modułowej budowie. Zdemontowany, uszkodzony moduł może być naprawiany niezależnie od całego silnika. W tym czasie zabudowuje się moduł zapasowy i silnik przekazuje do eksploatacji. Po naprawie uszkodzonego modułu staje się on elementem zapasowym. Liczba zapasowych modułów i silników jest jednak ograniczona, co limituje możliwość zamian.

Klucz Obsługi i Naprawy Silnika 31. Bazy Lotnictwa Taktycznego w Krzesinach jest w stanie wykonać większość prac obsługowo-naprawczych:

- „długotrwałe” naprawy modułów, w tym bardzo trudną i pracochłonną naprawę modułu głównego,

- sprawdzenia agregatów, elementów wyposażenia silników i modułów

- obróbkę mechaniczną części, naprawę lub odtworzenie połączeń nitowanych i spawanie metali twardych (stopów kobaltu)

- odtworzenie parametrów pracy silnika, jak również ich weryfikację na hamowni silnikowej

- prowadzenie prób na hamowni silników niesprawnych, przed rozpoczęciem ich naprawy - jest to konieczne w przypadku niesprawności o niewyjaśnionej przyczynie lub 
of unknown reason or impossible to eliminate or clearly diagnose by maintenance squadrons

- repair of bearing partitions

- disassembling of particular modules into basic parts in order to have them verified

- diagnosis of parts and generators of the engine

- analysis of the engine technical state, including drive shafts, turbine disks and bearing partitions

- combustion chamber repair

- repair of afterburner module at D-level.

It is significant to have appropriate number of generators and single use parts during repairs.

Rational use of materials, acquiring appropriate number of spare parts can contribute to make the time of repair shorter. Maintenance infrastructure is also an important question. The number of repaired engines depends on the number of maintenance points and maintenance equipment. Another problem is personnel training. Personnel of the opeartion keys in maintenance squadrons is trained during 3-month courses called "Engine Flight Line". Specialistic knowledge acquired during such courses fully satisfies requirements connected with engine maintenance, repair and engine replacement. Engine Maintenance \& Repair of the Technical Squadron these requirement are much greater. Personnel training is divided into 3 phases:

- Level 1 (Engine Backshop level 1) - the course combines general knowledge concerning engine construction, generators' functioning, documents using and assembling \& dissembling of engine into modules

- Level 2 (Engine Backshop level 2) - personnel is acknowledged how to disassemble modules into parts and how to repair modules

- Level 3 (Engine Backshop level 3) - personnel is prepared to analyse faults, calibration of engine systems and inspections performing.

Besides, all specialists working with engines can count on producer's help all the time. From the beginning of the F-16 implementation process, Pratt\&Whitney representative is present at the 31 st Air Base in Krzesiny. If more complicated faults occur, additional questions to the producers are sent.

First repair of the modules will constitute a great challenge for the engine maintenance personnel. On the contrary to earlier practice, it is not a standard procedure to send a whole engine to repair workshop. Before repair starts, engine must be dismantled, modules are packed into special containers (Fig. 10 and 11) and sent. It is also worth mentioning that it is the Engine Maintenance and Repair Key who is responsible for providing spare parts necessary for repair.

Time of module repair differs depending on the kind of a module. Main module repair is most time consuming and may last up to a year. Assembling of modules after a repair depends on the order in which they are obtained. It is necessary to avoid mixing modules which overhaul life differs a lot. Taking into account that Polish Air Forces have over 50 engines (type F100-PW-229) at their disposal and every niemożliwych do usunięcia czy jednoznacznego zdiagnozowania w eskadrach obsługi

- naprawę przedziałów łożysk

- demontaż poszczególnych modułów na podstawowe elementy składowe celem weryfikacji

- przeprowadzanie diagnostyki elementów i agregatów silnika

- analizę stanu technicznego silnika, w tym wałów napędowych, dysków turbin i przedziałów łożysk

- naprawę komór spalania

- remont modułu dopalacza w zakresie D-Level.

Istotne podczas napraw jest posiadanie w magazynach odpowiedniej liczby agregatów i części jednorazowego użytku. Racjonalna gospodarka materiałowa, pozyskanie odpowiedniej ilości części zapasowych może znacząco skrócić czas napraw. Ważne jest również posiadanie odpowiedniej infrastruktury naprawczej. Liczba naprawianych w tym samym czasie silników jest ograniczona do liczby stanowisk obsługowych i posiadanego sprzętu obsługowego. Kolejnym zagadnieniem jest wyszkolenie personelu. Personel kluczy eksploatacji silników w eskadrach obsługi jest szkolony na 3-miesięcznych kursach tzw. „Engine Flight Line". Zdobywany zasób wiedzy specjalistycznej w pełni zaspokaja wymagania związane z obsługą, naprawą i wymianą silników. W Kluczu Obsługi i Naprawy Silników Eskadry Technicznej wymagania odnośnie do wiedzy specjalistycznej są znacznie większe. Szkolenie personelu jest podzielone na 3 etapy:

- Poziom 1 (Engine Backshop level 1) - kurs obejmuje zapoznanie z ogólną budową silnika, działaniem agregatów, korzystaniem z dokumentacji oraz demontaż i montaż silnika na moduły.

- Poziom 2 (Engine Backshop level 2) - personel zapoznawany jest $\mathrm{z}$ demontażem modułów na części i wykonywaniem napraw modułów.

- Poziom 3 (Engine Backshop level 3) - personel jest przygotowywany do wykonywania analizy niesprawności, kalibracji systemów silnika oraz prowadzenia przeglądów.

Ponadto wszyscy specjaliści wykonujący prace na silnikach mogą w każdej chwili liczyć na pomoc producenta. W 31. Bazie Lotnictwa Taktycznego w Krzesinach od momentu rozpoczęcia wprowadzania do eksploatacji samolotów F-16 obecny jest przedstawiciel firmy Pratt\&Whitney. W sytuacjach bardziej złożonych niesprawności, wymagających dużej wiedzy i doświadczenia, wysyłane są dodatkowe zapytania do producenta silników.

Dużym wyzwaniem stojącym przed personelem eksploatującym silniki będzie pierwszy remont modułów. Inaczej niż to było praktykowane wcześniej, do zakładów remontowych nie wysyła się całego kompletnego silnika. Silnik przed rozpoczęciem remontu będzie musiał być zdemontowany, moduły zostaną spakowane do specjalnych kontenerów (rys. 10 i 11) i wysłane. Należy również nadmienić, że zabezpieczenie w części zamienne, konieczne do wykonania remontu, spoczywa na Kluczu Obsługi i Naprawy Silnika.

Czas trwania remontu modułów jest różny. Najdłuższy jest dla modułu głównego i może wynosić nawet rok. Składa- 


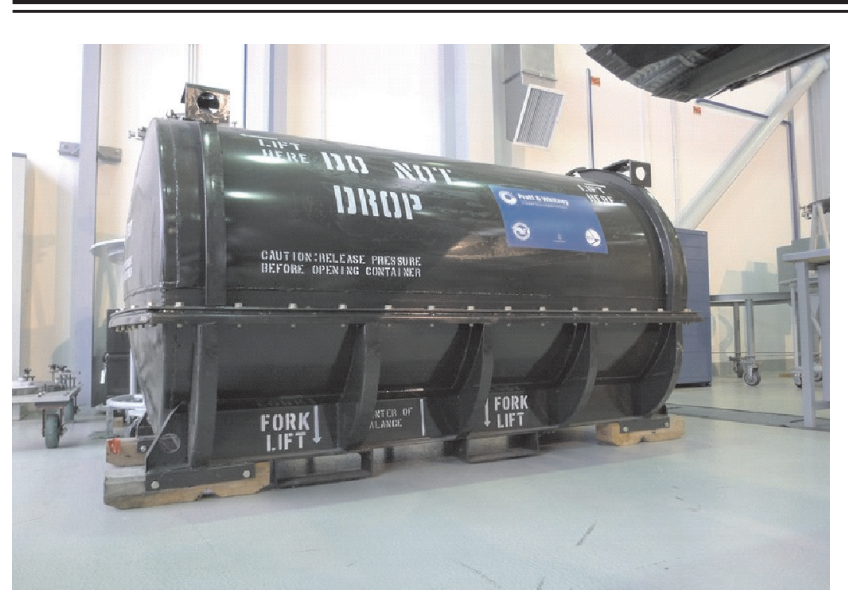

Fig. 10. Transport container for main module engine

Rys. 10. Kontener transportowy dla modułu głównego silnika

engine comprises 5 modules, amount of work to be done by Engine Maintenance \& Repair Key in 31st Air Base in Krzesiny when repair starts, will be huge.

Additional question which should be taken into account during engine use is overhaul life level. As engines has been handed over to the 31 st Tactical Air Base at the same time as aircrafts, the use of aircraft should be planned in such a way which would enable to dispatch modules for repair in prospect of many years. Cumulation of the number of engines with the overhaul life for the period between repairs can be limited only by appropriate overhaul life managing and changing of engines between airframes. Efficient repair needs close cooperation with Pratt\&Whitney which offers participation in Module Management Program. Participation in the program will facilitate repairs, in particular in question of providing spare parts.

\section{Summary}

When Polish Air Forces have introduced into operation Pratt\&Whitney F100-PW-229 engines together with F-16 aircrafts, they acquired access to modern technologies and methods of flight equipment maintenance. F100-PW-229 engine is one of the safest and most advanced in its class. It guarantees safety of flying and world quality performance and, thanks to modern avionics and weaponry system, F-16 aircraft represents advanced combat system which enables equality in cooperation with NATO countries. Advanced system of F100-PW-229 engine maintenance and repair described in the article provides its long and economically reliable operation.

\section{Paper reviewed/Artykut recenzowany}

Brig. Gen. Włodzimierz Usarek - commander of the $2^{\text {nd }}$ Tactical Air Brigade - garrison Poznan. Gen. bryg. pil. Włodzimierz Usarek - dowódca 2 Brygady Lotnictwa Taktycznego garnizonu Poznań.

e-mail: sekretariat2slt@interia.pl

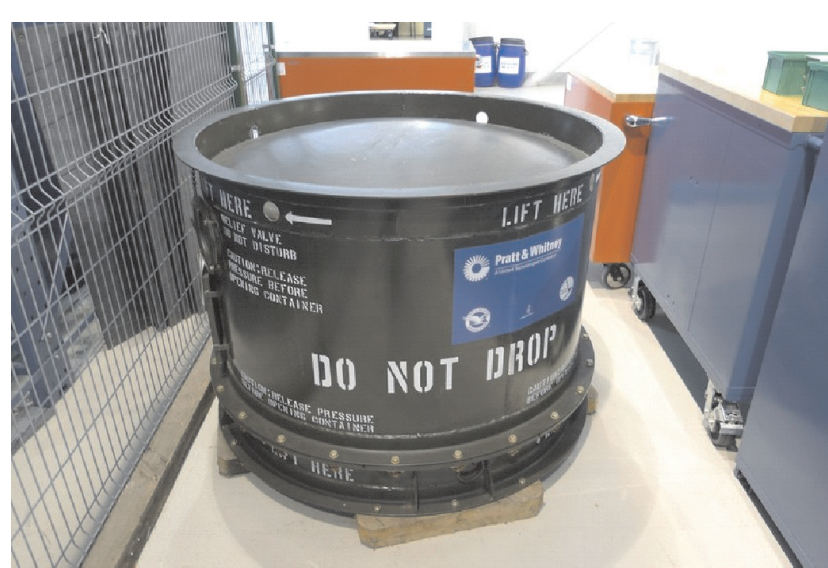

Fig. 11. Transport container for fan module

Rys. 11. Kontener transportowy dla modulu wentylatora

nie silników po remoncie będzie przebiegać zgodnie z kolejnością otrzymywania modułów. Należy przestrzegać zasady niemieszania modułów mających znacznie odbiegający od siebie pozostały resurs do remontu. Biorąc pod uwagę, że Polskie Siły Powietrzne posiadają ponad 50 silników F100PW-229, a każdy silnik składa się z 5 modułów, ilość pracy do wykonania przez Klucz Obsługi i Naprawy Silnika 31. Bazy Lotnictwa Taktycznego w Krzesinach, w momencie gdy rozpoczną się remonty, będzie ogromna.

Dodatkowym problemem, jaki należy uwzględnić podczas eksploatacji silników jest ich zużycie resursu. W związku z tym, że silniki zostały przekazane razem z samolotami prawie w jednakowym czasie, należy tak planować eksploatację silników, aby wysyłka modułów do remontu była rozłożona na przestrzeni wielu lat. Kumulację liczby silników z wypracowanym resursem międzyremontowym można ograniczyć tylko przez odpowiednie zarządzanie resursem oraz zamiany silników pomiędzy płatowcami. Sprawne wykonanie remontów będzie wymagać ścisłej współpracy z firmą Pratt\&Whitney, która proponuje uczestnictwo w programie zarządzania eksploatacją modułów MMP(Module Management Program). Uczestnictwo w programie znacznie ułatwi remonty, w szczególności w kwestii dotyczącej zabezpieczenia remontu w części zamienne.

\section{Podsumowanie}

Wprowadzając do eksploatacji w Polskich Siłach Powietrznych wraz z samolotem F-16 silniki F100-PW-229 firmy Pratt\&Whitney, uzyskano dostęp do nowoczesnych technologii i metod obsługi sprzętu lotniczego. Silnik F100PW-229 jest jednym z najbezpieczniejszych i najbardziej zaawansowanych w swojej klasie. Zapewnia bezpieczeństwo latania i osiągi na światowym poziomie, a dzięki połączeniu z nowoczesną awioniką i systemem uzbrojenia samolot F-16 stanowi zaawansowany system walki, dzięki któremu można na równi współpracować z siłami państw sojuszniczych NATO. Opisany w artykule zaawansowany system obsługi i napraw silnika F100-PW-229 zapewnia jego długą i niezawodną, a także racjonalną ekonomicznie eksploatację. 